\title{
The Narrowing Gap Between Vision and Execution: \\ Neoliberalization of PES in Costa Rica
}

\begin{abstract}
:
Recent work has called into question the status of Costa Rica's Payments for Environmental Services program (PES) as an iconic example of market-based conservation. The actual practice of this program has proven to have only loose correspondence with its idealized neoliberal vision. Thus far, however, several important aspects of the program have remained under-analyzed. This paper identifies three key ways in which the gap between "vision" and "execution" is being narrowed: through changes to the way the program is financed, through promotion of competitive contracting, and through the removal of collective participation. The paper also explains the detrimental social and ecological implications of these actions. Analysis is situated in a theoretical framework that understands neoliberalization as an incomplete and adapting process, rather than a monolithic ideology that is uniform across history and geography. The empirical evidence demonstrates why this interpretation is essential for assessing the practical effect of neoliberal policies.
\end{abstract}

Keywords: neoliberalization; PES; Costa Rica; conservation; governance; ecosystem services 
In a recent paper, Fletcher and Breitling (2012) demonstrate the many ways in which Costa Rica's Pagos por Servicios Ambientales program (PSA) ${ }^{1}$ fails to realize its vision for instating a market-based conservation mechanism. They rightly identify many aspects of the program that challenge its status as a "neoliberal conservation" project; it is largely financed through taxation, it was accompanied by an expropriation of land-use rights, markets for the sale of ecosystem services are virtually non-existent, and a state-centered structure utilizes a redistributive model to target priority areas identified through centralized planning. The implication is that the reputed success of Costa Rica's PSA in expanding forest conservation is largely the result of interventionist policies, not (as has been widely accepted) market-oriented ones. Their purpose is to suggest, among other things, that the future of initiatives being built upon such programs (eg. REDD+) may be problematic if they intend to rely on markets to sustain their activities.

While I am sympathetic to their effort to undermine the assumption that markets can be used to solve conservation problems - or as Buscher $(2012,30)$ puts it "that capitalist markets are the answer to their own ecological contradictions" - I will argue below that they have overlooked several key ways in which Costa Rica's PSA is being neoliberalized. My objective is to strengthen their position by demonstrating that, in the cases where neoliberalization has taken place, there have been detrimental social and ecological consequences. Whereas Fletcher and Breitling (2012) challenge the alleged success of market-based conservation by emphasizing the ways in which Costa Rica's PSA has failed to incorporate neoliberal practices, my approach to the same is to reveal the adverse effects of the "actually existing" neoliberalisms that have in fact been realized.

1 Pagos por Servicios Ambientales translates to Payments for Environmental Services. The Spanish abbreviation, PSA, is used here to refer to Costa Rica's national program, while the English version, PES, is used to refer to the generic concept of Payments for Ecosystem Services. 
This alternative approach addresses an important vulnerability that exists in the assertion that the practice of making payments for environmental services in Costa Rica has largely not followed a neoliberal development model. In response to such a reading, proponents of marketization could plausibly argue that the PSA has generated forest conservation despite its current form and that it could be improved through, for example, the "efficiencies" of the market. On the other hand, by exposing the detrimental implications of the neoliberal policies that have already entered practice, it is possible to preempt calls for further neoliberalization and even promote the reversal of what has already been achieved. Furthermore, by understanding neoliberalization as a process that is only ever partially complete, it is possible to take this line even while accepting Fletcher and Breitling's (2012) accurate depiction of the PSA as overwhelmingly non-neoliberal in practice. In the pages below, that is exactly what I will do.

In the first section, I provide context for this analysis by introducing the policy shift that instated PES and created an opening for liberalized conservation strategies in Costa Rica. In the second, I provide a theoretical framework for the analysis and explain what it has to offer for conceptualizing these activities. In the third, I expand on the position of Fletcher and Breitling (2012) that the practice of PSA departs significantly from the neoliberal vision laid-out in its design: first showing that the idea of making payments for environmental services in Costa Rica was formulated according to neoliberal principles, and then demonstrating the ways in which actual practice has failed to realize many of these objectives. Then I present my empirical study of the trend towards neoliberalization in Costa Rica's PSA, providing three concrete examples of neoliberal influence and explaining their consequences. Finally, I conclude with a discussion of implications and the importance of interpreting even subtle instances of neoliberal influence as significant. 


\section{I: Costa Rica's New Direction}

Costa Rican forest policy changed dramatically with revision of its national Ley Forestal in 1996 (Forest Law No. 7575). Under pressure from a third round of Structural Adjustment imposed by the World Bank, the new law eliminated the preceding "certificates" scheme, so the government would (theoretically) no longer directly subsidize any forest management activities (Watson et al. 1998, 74). In its place, the law made provisions for a system that would encourage particular land uses through establishment of financial links between individual users and producers of "ecosystem services" - it formed the legal basis of the PSA program. As identified by Blackman and Woodward $(2010,1628)$, a "major motive for creating the PSA program was to recast reforestation and conservation subsidies as payments for environmental services". Essentially, it sought to reorganize the foundation of how environmental conservation was carried out in Costa Rica. The PSA re-framed conservation in economic terms that saw degradation as the result of "market failures" to internalize the true value of functioning ecological systems (Rodriguez, pers. comm., 2 Feb 2012).

Fundamentally, the new program altered the rationale for support of forest management. What had been aid for prescribed land uses was re-conceptualized as compensation for service provision. Interpretation shifted to cast earlier forms of conservation support as assistance for practices that were not economically viable, while new approaches are framed as remuneration for astute asset management. This meant landowners that were supported by these new conservation regimes could be regarded as "deserving" resource managers, as opposed to subjects of welfare dependency. It is clear that the very core of how conservation support is delivered in Costa Rica shifted with the passage of the 1996 Forest Law, and that the underlying ideology of the new approach is largely rooted in a neoliberal worldview. 
While Feltcher and Breitling (2012) have already shown that a significant gap exists between the neoliberal vision of the PSA and its actual practice, proponents of marketization have eagerly sought to change this. In the pages below, I will demonstrate the ways in which they have proceeded towards this goal, but first I will step back to review the difference between an analytical framework built on the concept of neoliberalism as an ideology versus one built on an appreciation of neoliberalization as a process. The purpose is to demonstrate how, despite the gap between the neoliberal vision and actual practice, it is possible that neoliberalization is still actively taking place.

Importantly, this is not intended to suggest that the conceptualization of neoliberalism put forward by Fletcher and Breitling (2012) is somehow lacking sophistication, or even that it does not appreciate the hybrid and piecemeal character of "actually existing" neoliberalisms. Drawing on Foucault (2008, 218), they explain that their perspective "views neoliberalization in conservation policy not merely as an economic program but as a 'whole way of thinking and being,' ... that is, an overarching approach to governing human behavior in general" $(2012,404)$. They are careful to acknowledge that neoliberalism is invariably expressed "in syncretism with alternate conservation strategies and local sociocultural formations" (ibid.). Despite this, however, their analysis emphasizes the ways in which neoliberalization has failed to influence the PSA, rather than the ways in which it has taken root. As a result, they have overlooked some important instances where neoliberal policies have already begun to enter practice. In order to shift the focus toward the real effects of neoliberalization, I suggest the conceptual framing below that underscores the process as a perpetually unfinished project.

\section{II: Neoliberalism vs. Neoliberalization}

The "neoliberal" label is often used quite loosely to refer to any form of pro-market ideology. This imprecision has been criticized by scholars on the grounds that it results in the loss of meaning, 
becoming "nothing more than a vehicle for academics who like to criticise things that they do not like" (Igoe and Brockington 2007, 445). Despite its loose usage, the ideology of neoliberalism is quite clearly defined (and generally agreed upon) by the community of scholars critically engaging with it. Neoliberalism is an economic concept that stresses free trade, private enterprise, and a limited role for government, and it is most often embraced by political conservatives. As identified by Castree (2008a, 142-143), the key features of neoliberalism include: privatization (the transfer of "previously stateowned, unowned, or communally owned" property to private hands), marketization (the assignment of prices through market mechanisms to facilitate exchange), deregulation (the ''roll-back' of state 'interference"' in markets), re-regulation (the "deployment of state policies" to support those markets), the development of market proxies (the restructuring of the "residual public sector" to operate more like the private sector), and an array of flanking mechanisms (such as charities, NGOs, and private organizations) to fill the void left by the state. Various other interpretations may include decentralization and "devolution of governance to non-state actors" (Fletcher and Breitling 2012, 402), and the primacy of individual liberty over communal responsibility.

Of course, as Fletcher and Breitling (2012) have already shown in the case of Costa Rica's PSA, practice rarely aligns perfectly with ideology. The archetypal conception described by Castree almost certainly exists nowhere as such - indeed, he acknowledges that his characterization is an abstraction of "multiple 'neoliberalisations' extant in the world" (2008a, 142; 2008b). Does this mean, then, that the critiques of neoliberalism are little more than swipes at a straw man? If nothing is ever truly neoliberal, are so many social ills really attributable to it?

The answer is in understanding neoliberalism not as a monolithic force that displaces previous modes of economic governance, but rather as a process that is incomplete and ever-adapting (Peck and Tickell 
2002). It is not essential that every aspect of the idealized neoliberalism exist for neoliberalization to be occurring, and it is not essential that the process be complete for detrimental consequences to emerge. Neoliberalization can even exist simultaneously with overtly non-neoliberal practices, when new policies interact and overlap with existing ones - it is the messy product of complex histories and diverse geographies. "Actually existing" neoliberalisms, Brenner and Theodore (2002) explain, are the result of context- and place-specific histories, rather than grand location-independent theories. In this sense, the result of neoliberal policies is always multiple neoliberalisms, according to local conditions. They are frequently, therefore, ideologically fragmented and may only vaguely resemble each other when compared across space and time - neoliberal reform leads to divergent outcomes, "not ... a neoliberalized end of history and geography" (Peck and Tickell 2002, 383).

Since there is no finished product, no point at which the neoliberalization process is complete, neoliberalism can exist even in cases that deviate substantially from the idealized conception. When it is present, it is always to varying degrees according to the success of its promotion, its confluence with existing regimes, and the resistance mounted against it. That is why, in the case of Costa Rica's PSA, no matter how overwhelmingly non-neoliberal actual practice proves to be, there is still the possibility of encroaching neoliberalization. It is important, therefore, to uncover and assess even the most subtle instances of neoliberal influence, in order to understand the serious consequences that can often still exist.

Nevertheless, the smooth-edged conceptualization presented by Castree (2008a) serves a purpose in its own right. The "ideal type", as articulated by sociologist Max Weber, helps to order our perception of disordered reality (Weber 2007 [1904]). It is intended to represent a distillation of actually existing cases, even though it may only ever have loose correspondence to any one of them. It constitutes a 
reference point that helps to bind our research together, so that broader-scale conclusions can be drawn. While caution against "overly universal understandings" is advisable, the ideal-type provides structure for reading across empirical studies (see Bakker 2009; Castree 2009), allowing them to be seen as more than just "a patchwork of qualitatively distinct parts that are relatively incommensurable" (Castree 2008b, 155).

There is danger, however, that the ideal-type can be misinterpreted as comprising the necessary and essential elements of a phenomenon, rather than serving as a device for conceptualizing it. In that case, the focus shifts to extreme examples and risks overlooking actual cases where certain elements exist only to a degree. In other words, it has a tendency to make the real thing seem as though it is not a perfect representation of itself. In assessing the "neoliberalness" of Costa Rica's PSA, for example, it would be a mistake to conclude that it has no neoliberal characteristics simply because it lacks certain “ideal" elements (eg. markets) or includes other antithetical ones (eg. government involvement). The pragmatic view put forward by Farley and Costanza (2010) that PES can be carried out without being market-based, then, can even be interpreted as endorsing "a neoliberal project writ large" (Fletcher and Breitling 2012, 409).

The importance of understanding how neoliberalism operates and how to identify it, of course, is rooted in the implications that it has for society and the environment. As Harvey (2005a) demonstrates, neoliberal policies are (one of) the fundamental causes of uneven development and declining prosperity for the most vulnerable segments of the population. As conservation is drawn under the logics of neoliberal economics, nature becomes just the latest grounds for capital investment, re-framing conservation "as an accumulation strategy" (Katz 1998, 48; Smith 2007) and ultimately opening new spaces for "accumulation by dispossession" (Harvey 2005b). By concealing the social and ecological 
context of "service" production, power asymmetries are reproduced and inequalities are expanded (Kosoy and Corbera 2010). The emergence of this new approach to environmental conservation, then, can be interpreted as just the latest stage of uneven development under the capitalist mode of production.

\section{III: Vision and Practice}

The move to marketize conservation in Costa Rica, of course, was framed in far more benign terms by those in favor of economic liberalization. From that perspective, markets would promote efficiency and bring "financial sustainability" to conservation efforts by replacing (what are presumed to be) unreliable sources of government financing (World Bank 2000). A vision to achieve this was laid out in the PSA. As Fletcher and Breitling have already shown, however, there exists a "significant gap between vision and execution" in the program $(2012,408)$. In agreement with this assessment, I will provide further evidence that the PSA was conceived with a profoundly neoliberal vision, but executed in ways that more closely resemble the conventional systems that it was meant to replace.

\section{Neoliberal Vision}

When the new forest law passed and the PSA was established, ambitious designs were laid by those critically positioned to influence the program's direction. Sage and Sánchez (2002), for example, envisioned radical possibilities that would realize marketization and facilitate state withdrawal. In a short paper, the two employees at FONAFIFO (the Costa Rican agency implementing the PSA) laid out what the program had the potential to become. ${ }^{2}$ Beginning with the initial form of the new program, they re-conceptualized the PSA not as a subsidy, but rather as government "purchases" of "service rights". They then envisioned the program's evolution through several iterations that would first link

2 Sánchez is listed as "Environmental Services Section Chief", and Sage is listed as "Consultant in charge of the FONAFIFO project”. 
producers with users in a government-sustained quasi-market, then create a tradeable "certificate" of environmental services (essentially a packaged commodity representing an abstract ecosystem service), then facilitate the formation of an investment market for those certificates, and finally culminate in the withdrawal of government from the program and idealized direct financial transactions between users and producers taking place in open markets (Sage and Sánchez 2002, 73). ${ }^{3}$

The vision laid out by the two is somewhat idealistic, offering almost no commentary on how it was to be achieved or how, for instance, direct agreements between users and producers could be sustained without some sort of coordinating body. What their paper illustrates, however, is that the concept of PES was being understood in neoliberal terms by (at least some of) those working to carry it out. Even though early stages of the PSA may have resembled previous modes of supporting conservation, a fundamental change in the ideology underlying the practice had taken place. Within the institutions tasked with implementation, the PSA was being treated as far more than just a change of name for direct subsidization (Sage and Sánchez 2002).

\section{Actual Practice}

While the idea of PES clearly represents a new direction for socio-environmental management, the practical transition has proven far more gradual. Indeed, many of the actual practices of making payments for environmental services in Costa Rica do not map neatly onto a neoliberal model. First, there was a level of continuity from the previous management regime to the current one, in that the new regime initially supported all the same land-use practices and carried over the same payment levels from the certificates scheme (Pagiola 2008). Moreover, several aspects actually extended previous approaches to conservation, particularly with regard to program financing. Initially, the PSA was

3 The "certificates" mentioned here should not be confused with the earlier system of certificates, as they represent a commodified service, not (as previously) a bond issued as direct government payment. This new certificate has already been realized as the Certificado de Servicios Ambientales, or Certificate of Environmental Services. 
funded almost entirely by a new tax on fossil fuels (Sánchez-Azofeifa et al. 2007). As Fletcher and Breitling (2012) point out, this was intended to be a temporary measure that would be replaced by revenue generated on international carbon markets, but when those markets failed to materialize, the tax remained. Even as the program has progressed, the proportion of financing that could be regarded as market-based remains wholly insignificant, amounting to $0.5 \%$ since the start of payments (FONAFIFO 2011). ${ }^{4}$

In fact, the involvement of markets has failed to materialize on several fronts. Payment levels are actually set at fixed-rates by presidential decree, rather than determined by demand on an open market (Pagiola 2008). This means that a single payment level exists for each contract modality so that each PSA participant receives the same per-hectare rate for equivalent management. Payments do not, therefore, reflect the variability of opportunity costs or the market value of productive land. This has led to claims that the PSA is "overpaying" in some cases and offering inadequate incentives in others (World Bank 2007). Despite criticism of this "inefficiency” (Wünscher et al. 2008; World Bank 2007), the government has resisted pressure to implement market-oriented valuation techniques such as reverse auctions (Chomitz et al. 1999), contingent valuation (Whittington and Pagiola 2011), or other mechanisms for price differentiation (Sills et al. 2005).

A consequence of fixed-rate payments is that supply and demand do not come to a "natural" balance. For the PSA, this has meant that demand for participation routinely outstrips the availability of financing (Pagiola et al. 2005). As a result, a prioritization scheme and applicant selection process has been required. This has meant further government involvement and distancing from the idealized vision. Operation guidelines, also set through presidential decree, have consistently identified priority

4 This was calculated using the sum of revenues generated from contracts with Florida Ice and Farm, various hydroelectric companies, and CSA sales and the total FONAFIFO budget for PSAs: $100 * \not \subset 507,539,487 / \not \subset ~ 99,797,775,525$. 
“biological corridors" and criteria for targeting high poverty areas (see Zhang and Pagiola 2011).

These measures indicate that the Costa Rican government (broadly speaking) is concerned with pursuing a particular socio-ecological vision over unrestrained market-rule. ${ }^{5}$

The strictest government regulation that accompanied the development of the PSA, and the one that most directly conflicts with liberal conceptions of governance, is the outright ban on land-use conversion. As Fletching and Breitling point out, this regulation makes the new forest law "something of a paradox" that simultaneously promotes "neoliberalization and state intervention" $(2012,407)$. When the law was passed, some feared the inadvertent creation of perverse incentives that would, for example, encourage the removal of primary-growth forest for the purpose of accessing reforestation funds (Watson et al. 1998), as had occurred previously under the certificates scheme (Morell 1997). So along with the measures to reform the conservation incentive scheme came provisions that restricted an owner's right to convert forested land to other uses - it became illegal to cut "natural" forest for the purposes of harvesting timber, producing agricultural or pastoral lands, or bringing about any other form of development. ${ }^{6}$ It effectively extends state (and restricts private) control of resources. As a result, opposition to the new law was (at least initially) quite strong by some environmental economists. For example, Bruce Aylward noted that the measure "effectively expropriates land use rights on forested terrain" and is "both ecologically and economically flawed" (quoted in Watson et al. 1998). This ban on land-use conversion shows that, in certain ways, Costa Rica's implementation of PES is strongly contradictory to fundamental features of neoliberalism.

5 While these priority areas appear to be the product of state-level planning intended to promote a particular socioecological vision, further investigation is warranted to determine if the principles of "economic efficiency" are a factor in their formation. If, for example, biological corridors are formed with the intention of directing scarce resources to areas that provide greater services, rather than areas of particular biological importance, this could actually be an example of emergent neoliberalization.

6 A mechanism for "sustainable forest management" remained in place until 2003, wherein selective cutting was permitted under strict management plans (World Bank 2007). 
Clearly, there exists a disconnect between the PSA concept and actual practice, as the new program bears great resemblance to the one it replaced. Though the PSA represents a fundamentally "new" way of carrying out conservation activities, the endurance of overtly state-centered practices render it almost unidentifiable as neoliberal against the idealized model. Understandably, this has led some (eg. Rojas and Aylward 2003; Watson et al. 1998) to characterize the PSA as little more than a continuation of older subsidy-based policies. However, the work of critical scholars is emphatic about the tendency of states to expand, in their efforts to form and sustain neoliberal markets (Peck 2010; Peck 2004; Larner and Craig 2005). Thus, it is possible that the shift in ideology embodied by the PSA can represent the onset of the neoliberalization process, despite the many overtly non-neoliberal practices that have endured. As recognized by von Platen, the "economic implications of the change" to conservation policy are such that "there is indeed more to it than a simple change of name" $(1999,23)$.

Despite Fletcher and Breitling's careful recognition that neoliberalism is never expressed in its idealized form and that neoliberalization can exist alongside overtly anti-neoliberal practices, their assessment casts considerable doubt on the "neoliberalness" of Costa Rica's PSA, going as far as asking to what extent institutions can "deviate from a free market ideal before they can [no] longer properly be labeled 'neoliberal' at all" $(2012,410)$. Their suggestion is that when "ostensibly neoliberal structures are actually supported by decidedly non-neoliberal practices", they may not be "amenable to characterization as 'neoliberal' at all in any meaningful sense" (ibid.). In my view, whether or not the "neoliberal" label can be attached to the program as a whole may be less important than whether or not certain aspects have undergone a degree of neoliberalization great enough to have measurable detrimental consequences. As I will demonstrate below, specific concrete interventions by market proponents are, in fact, having this effect in Costa Rica's PSA. 


\section{IV: The Process of Neoliberalization}

Notwithstanding the important challenges to its characterization as a "paradigmatically neoliberal 'market-based' conservation mechanism" (Fletcher and Breitling, 2012, 402), the PSA is being neoliberalized in (at least) three important ways: the way in which it is financed, the way in which labor is managed, and the way in which landowners participate. I take each in turn to explain the changes that have occurred and illustrate what the effects have been.

This research is based on a combined approach of open-ended interviews and critical analysis of policy and project documents. Interviews were conducted, in person and via Skype, during a 5 month period at the end of 2011 and beginning of 2012. They included key figures in the administration, operation, and policy formulation, such as government officials, development specialists, forestry engineers, landowners, and organization representatives from institutions such as FONAFIFO, the World Bank, Colegio de Ingenieros Agronomos, Instituto Tecnológico de Costa Rica, FUNDECOR, Conservation International, ASANA, ASIREA, CEDARENA, IngeoFor, and the Asociación Corredor Biológico Talamanca Caribe. This work draws on over 10 years of contact with Costa Rican conservation and environmentalism, in both academic and professional capacities. The primary group of documents analyzed were those associated with two World Bank projects targeted at Costa Rica's PSA (the Ecomarkets Project and the follow-on Mainstreaming Market-based Instruments for Environmental Management), but also include those produced by FONAFIFO, its agents, and consultants.

\section{Neoliberalization of PSA Financing}

First, while the PSA has failed to develop the market financing that was promised (Sage and Sánchez 2002), a trend towards neoliberal financing mechanisms is still evident in its various revenue streams, namely in the differences between the fuel tax and water tariff. The fuel tax was established under the 
same law that initially instituted the PSA, while the water tariff was developed later, in 2006, as the Ministry of Environment (MINAE) ${ }^{7}$ sought to expand the program. The fuel tax levies a charge on gasoline sales to finance PSA activities. It is possible to interpret the tax as a "payment" by users of carbon sequestration services (since emitters of carbon are being charged to counterbalance their emissions with forest expansion), however, most analysts reject this interpretation. Pagiola, for example, insists such a revenue stream can "only tenuously be regarded as a payment by service users" because it is non-voluntary and funds are "not used solely to generate carbon sequestration" (2008, 715-716). This, of course, is the nature of a tax; revenues are collected and then redistributed to achieve particular social and ecological objectives. This flexibility has served the PSA well in that it has allowed targeting of priority conservation areas identified through various ecological studies (eg. the GRUAS reports; Zhang and Pagiola 2011) and prioritization of lesser developed communities through use of the Social Development Index (Porras 2010). Existing issues notwithstanding ${ }^{8}$, the ability to target the program is critically important to protecting the interests of vulnerable communities and ensuring that the most ecologically important areas receive first preference.

The water tariff, on the other hand, works quite differently; fees are collected from holders of water concessions, and a percentage is transferred to the PSA for use within the watershed in which the revenues were generated. The language, as it appears in the presidential decree, explicitly states that revenues cannot be transferred to other watersheds and cannot be used to pay for the provision of other services (eg. carbon sequestration or biodiversity conservation) (Decree 32868-MINAE, Chapter IV, Article 14). ${ }^{9}$ This stipulation on where tariff revenues can be used derives from the idea that only those

7 The full name of the agency that established the water tariff is the Ministry of Environment and Energy, abbreviated "MINAE". It has since become the Ministry of Environment, Energy, and Telecommunications, or "MINAET".

8 A recent study has shown that an increasing share of the PSA "payments" is being captured by wealthy corporate and foreign investors (Porras 2010). This problem arguably arises from prioritization based on regional instead of individual social criteria - use of the Social Development Index gives a slight preference to the poorer regions of Costa Rica, but it does nothing to ensure it is the poor within those regions who benefit.

9 The decree states that tariff revenues are to be used to finance payments on "terrenos privados dentro de la cuenca donde se genere el servicio ambiental de protección del agua y se ubiquen en zonas de importancia para la 
who benefit from the services should have to pay for them - it is an attempt to bring the PSA closer to the idealized vision of "user fees". Though it is still criticized for its non-voluntary nature (Pagiola 2008), the World Bank appears to consider the tariff as progress towards the ultimate objective of direct user/provider transactions. Documents from the Bank's "Mainstreaming Market-Based Instruments" project (aka Ecomarkets II) cast the tariff in a favorable light, praising its ability to generate finances "which directly correspond to users of the services" (World Bank 2006, 12).

The difference between the "tax" and the "tariff" is more than just semantics. Rather than representing an expansion of taxation, as Fletcher and Breitling $(2012,408)$ suggest, the water tariff is, in certain ways, a step away from it. The tariff was designed to be anti-redistributive. Unlike the fuel tax, the tariff is limited in how revenues may be used to target important ecosystems or to assist lesser developed communities. For example, it is unable to finance conservation of areas of high biological importance if they fall outside of any watershed with water concession holders, and it cannot prioritize impoverished areas if no concession-holding industry is located there. Indeed, early analysis has already found that much of the revenue generated from the tariff "must be spent in areas that are not priority biodiversity conservation areas", that "the areas to which the bulk of watershed payments are targeted are simply not the poorest", and that "where watershed payments and low social development coincide, available funding is too limited to have a significant impact" (Zhang and Pagiola 2011, 413414).

The water tariff reorients the PSA under the logic of liberal economics, rather than the objectives of conservation or social development. The implications of this are extensive. Most importantly, those who reside in "wealthy" watersheds (i.e. those with significant water concession holders) receive a 
disproportionately greater share of the benefits of the PSA. The result, therefore, is geographically uneven patterns of conservation development. While the concept (that only those who benefit from the services are required to pay for them) may at first glance be attractive, the extension of its logic is far less acceptable: only those who can afford to pay for services are able to access them. The design of the water tariff risks unjust distribution in the name of realizing the conceptual purity of direct user/provider transactions.

If it seems a stretch to claim that the tariff (a fee levied by the State) is a form of neoliberalization, we must only recall that the state frequently plays an important role in forming and sustaining neoliberal markets and that not "all government intervention is inherently anti-neoliberal" (Fletcher and Breitling 2012, 409). Furthermore, the tariff contains a provision that allows water users to opt-out of paying the tariff directly by, instead, entering into a voluntary agreement for service provision (Pagiola 2008) - the idea being that this will encourage reluctant buyers (or "free riders") to enter the market.

\section{Neoliberalization of Forestry Work}

Second, the forestry industry has undergone dramatic restructuring that has had important effects on both the experience of work and the operation of the PSA program. Here, I focus on the latter - that is, how the decentralization and privatization of labor shapes who benefits from payments for ecosystem services. Much of this can be traced to institution of the regente system. Regentes forestales, literally "forestry regents", are professional forestry engineers that are responsible for the on-the-ground implementation of most aspects of forest management in Costa Rica. The system was created during a period of broader government decentralization and was designed to replace the General Forestry Directorate (DGF), a government office, with a network of individual private foresters (Silva 2003). It predates the PSA by several years (Rodríguez Zuñiga 2003), but is central to its operation. 
In order for a landowner to participate in the PSA he or she must present an application to FONAFIFO consisting of a land management plan and other supporting documents. Management plans must be written by a licensed regente. Most regentes operate as independent contractors in the private sector and are compensated for their work through a percentage of the payments made to their client landowners from PSA enrollment. ${ }^{10}$ The rate that independent regentes are paid is agreed upon with each of their client landowners and set in a contract. There is a legally mandated limit of $18 \%$ for regente fees, but otherwise the government plays no role in regulating agreements to ensure just outcomes. Instead, the rate charged is usually determined by factors such as contract size, contract modality, ${ }^{11}$ and ease of site access (Valenciano, pers. comm., 7 Feb 2012).

Apart from submission of prepared applications and an occasional inspection, regentes have little contact with FONAFIFO, the quasi-governmental agency responsible for managing PSA finances. ${ }^{12}$ Regentes are paid directly by their clients and supported by their professional association, rather than being employed by the government and receiving a salary from the ordinary budget. This decentralization has created a private industry of professional foresters that operates independently from most government functions (Silva 2003).

The implications are vast. Most significantly, it appears to achieve something promoted among market proponents: a system of competitive contracting wherein regente compensation stabilizes at the most

10 A small minority works as salaried staff for non-governmental organizations or cooperatives.

11 Modalities currently allowed under the PSA are conservation (aka protection), forest plantation (aka reforestation), agroforestry, sustainable forest management (i.e. selective cutting of "natural" forests), and natural regeneration. The conservation modality has further subcategories for protection of forests in hydrologically important areas and "vacios de conservación" - each offers higher payment rates than regular forest protection. For more details, see Ortiz (2011).

12 FONAFIFO, or the National Forestry Financing Fund, was originally created to manage PSA finances. It was given a special hybrid public/private status to allow greater flexibility in managing the various revenue streams, allowing it access to public finances, but sheltering private revenue streams from ordinary bureaucratic channels. Because of its reputation for efficient management, it was given expanded responsibility over the PSA in 2003, taking over applicant selection and oversight from SINAC. 
“efficient" levels. In other words, competition drives lower, where possible, the rate that regentes charge for their services, thus avoiding "waste" in overcompensation. There is evidence that this has taken place in Costa Rica. At the start of the program, most regentes charged a standard across-theboard 18\% rate (Ewing, pers. comm., 13 Jan 2012), but as it has progressed, competitive forces have driven rates down as low as 6 or $8 \%$ in some cases (Valenciano, pers. comm., 7 Feb 2012; Zuñiga, pers. comm., 30 Jan 2012). ${ }^{13}$

There are some obvious benefits here; lowered regente fees means a greater share of the budget is used to generate ecosystem services and less is used for program administration. However, closer examination reveals that competitive contracting disproportionately benefits the wealthier larger landowners (explained below) and may even be harming the most vulnerable participants by undermining collective participation (explained in the following section).

Competition has not caused the cost of participation to decline for all landowners. Because most of the costs associated with preparing PSA management plans are fixed (Miranda et al. 2003), the potential for savings is correlated with contract size. In other words, savings are greater on large contracts. The result of fostering competition, therefore, has primarily been lower per-hectare costs for large landowners, not across-the-board lower rates for all participants. Small landowners are still charged upwards of $18 \%$, due to the fixed costs associated with contract preparation. This affirms Silva's (2003, 112) assertion that "the regente system privileges larger landowners over smallholders and poor peasants" $(2003,112)$. In some cases, the smallest landowners are excluded entirely. As explained by one active regente (Zuñiga, pers. comm., 30 Jan 2012), contracts less than 30 hectares are often too small to justify the expenses of contract preparation, particularly in cases that require significant travel. Clearly, competition has given a comparative advantage to larger landowners and, thus, is actually 
contributing to an expansion of wealth disparity.

Of course, both proponents and opponents of marketization want the greatest amount possible to go towards service generation rather than administration, but the assumption of those who favor the competitive independent contractors model is that this cannot be achieved under a system that offers a more equitable flat-rate regardless of contract size or location. This position derives from an oversimplified conceptualization of human behavior which presumes regentes will charge as much as possible unless checked by competitive market forces. As McAfee suggests, however, "economically 'rational' behaviour aimed at individual gain is often less determinant than social obligations and communal norms” (2012, 118). Another regente (Alfaro, pers. comm., 23 Jan 2012), for example, explained that he continues to offer his services through a community development organization in spite of the fact that he could earn more drafting PSA contracts independently. Relying on this sort of social responsibility, it is possible to envision a model that spreads enrollment fees across the population without compromising regente performance or raising the overall cost of administration (lowered rates for small landowners could be offset by only marginal increases for large ones). In fact, a collective participation model aimed at distributing costs existed in Costa Rica until it was undermined by further neoliberalization.

\section{Neoliberalization of Landowner Participation}

The third example is closely related to the second and concerns a shift from collective to individual participation in the PSA. The contratos globales, or "global contracts", were developed early on as a form of group contracting intended to level transaction costs, making it no more expensive for small landowners to participate than it is for large ones. It was developed in direct recognition of the high fixed costs of contract preparation and comparative disadvantage for small landowners (Pagiola et al. 
2005). The idea was that landowners could pool their resources under a single contract, thus reducing the per-hectare rate for all involved. However, the mechanism was met with several challenges, including how to handle instances of individual non-compliance and ownership change within the groups. As designed, problems with single members could cause payment delays or even contract invalidation for the entire group (Porras 2010). In response, the mechanism was revised to culminate in individual contracts (Pagiola 2008); applications can still be entered as groups, but each member is ultimately issued a contract independent from others. This, of course, provides a solution to the partial compliance problem, but it results in "much smaller savings" (Pagiola 2008, 722) and undermines the coherence of collective participation. It effectively constitutes the individualization of participation in the PSA, which is consistent with the ideological preferences of neoliberalism. In fact, the individualized contracts change the practice so fundamentally that the head of PSA at FONAFIFO characterizes the contratos globales as having ended completely (Sánchez, pers. comm., 15 Feb 2012; for more on the "end" of group contracting, see Porras 2010). ${ }^{14}$

Further undermining collective participation is the system of competitive contracting described in the previous section. As regentes offered progressively lower rates to owners of larger lands, many were drawn out of groups designed to distribute savings, carrying away the ability of organizations to remain active in group contracting. Certainly, landowner decisions are not mere matters of economic calculus motivated by personal self-interest, but the evidence does suggest that a sufficient number of larger landowners have been lured away to make the practice unfeasible for some organizations. ASANA, an organization in the Dominical area, for example, withdrew from coordination of group contracting because they could no longer compete with the rates being offered by independent regentes to the individual owners of larger lands (Ewing, pers. comm., 13 Jan 2012). Clearly, the competitive system

14 It should be noted that, while participation has been individualized for all ordinary contracts, collective indigenous participation currently remains. 
is discouraging "cooperative behavior for the development of peasant or smallholder communities" (Silva 2003, 113). If fact, because their budgets are often tied to revenue generated from regente services and "they get more revenue per staff member by accepting large projects" (ibid.), some of the organizations that formerly protected small landowner interests have been pulled into the business of competitive contracting, making them the virtual equivalent of private profit-driven institutions operating in a market-based system.

Perhaps surprisingly, many pro-market perspectives had identified group contracting as a novel means of making the PSA accessible to the poor (Pagiola et al. 2005; World Bank 2006; World Bank 2007). Few, however, appreciated the need to actively foster and develop it. The decline of collective participation can be partly attributed to institutional neglect and the laissez-faire attitude of liberally minded actors influential to program management. From this perspective, collective participation is interpreted as something that spontaneously emerged to fill a need (in the sense of Hayek's spontaneous order premise), not something that required active support. This is evident in Chomitz, Brenes, and Constantino (1999), for example, where the claim is made that a number of NGOs "spontaneously adopted" the role of project "bundlers" in the Costa Rican system (pg 161). In fact, confidence that the provision of such needs would self-regulate appears to be so great that the decline of collective participation has gone largely unnoticed; reference to group contracting as a means of assisting poor landowners has continued to be made well after it was abandoned in 2002 (eg. Bennett and Henninger 2008; Pagiola et al. 2005; Sills et al. 2005; World Bank 2006; World Bank 2007).

Granted, the individualized version of "group contracting" that exists today - the version that has very little cost saving benefits for small landowners - still retains some important advantages. For example, organizations that assemble group applications often reach out to landowners that might otherwise lack 
the social capital or knowledge to get involved on their own. However, as this remains the initiative of independent organizations, it is clearly not an important priority for the program as a whole.

Otherwise, such outreach might be integrated as a central component to regular operations, not left to development organizations.

The effect of individualization further compounds the problem of large landowner advantage. The removal of the ability to collectively participate in the PSA substantially diminishes access for the poor. As the balance of participation shifts from groups to individuals and corporations, an increasing share of PSA benefits is being captured by larger, wealthier (and often foreign) landowners (Porras 2010). It is a troubling prospect that I have attempted to demonstrate is directly correlated with the PSA's gradual neoliberalization.

\section{V: Conclusion}

The objective of this paper has been to demonstrate that there are, indeed, some important ways in which Costa Rica's PSA is being neoliberalized, despite the overwhelming evidence that shows it is largely not a market-based conservation mechanism. Clearly, there are many factors that call into question the program's status as a neoliberal conservation project, but as the PSA represents a fundamental shift in underlying ideology, it is also more than just a continuation of older state-centered approaches to conservation management. Fletcher and Breitling are correct that the PSA is hardly the "quintessential market mechanism" that it is often characterized to be, but I do not agree that it "could equally be described as a subsidy in disguise" $(2012,408)$.

I have built upon Fletcher and Breitling's accurate depiction of the PSA as broadly failing to realize the neoliberal vision that was laid out for it, but I have also shown three concrete ways in which neoliberal 
policies are starting to emerge: in program financing, in labor management, and in landowner participation. Even though the program may never resemble the radical vision laid out by Sage and Sánchez (2002), the neoliberal changes that are occurring warrant cautious evaluation. As I have sought to demonstrate, even minor changes can have far-reaching consequences.

My emphasis is placed on revealing the detrimental effects of the instances where neoliberalization has in fact taken place. The purpose is to go beyond the suggestion that markets may not be able to sustain these sorts of conservation programs to suggest that they can actually have social and ecological consequences that are counterproductive to their intended objectives. This position forecloses on arguments that could plausibly be put forward by market proponents responding to Fletcher and Breitling (2012) - that is, that Costa Rica's PSA has been successful despite the gap between vision and execution and that it could be improved by introducing further neoliberal reforms.

The commentary above shows that, in each case where neoliberalization has occurred, the result is uneven development, consolidation of control over resources, and accumulation of benefits among wealthier, larger landowners: modifications to the way the PSA is financed has led to a realignment of conservation policy to be based on economic (rather than social or ecological) priorities; privatization of forest management has led to conditions more favorable for the participation of large landowners; and individualization of contracting has led to the erosion of support for small landowner participation. This is consistent with broader critical analysis of neoliberalism (Harvey 2005a) - the interests of capital routinely intervene to consolidate control over resources and accumulate wealth. Importantly, however, as this paper suggests, practices do not need to be overtly or even completely neoliberal to have these undesirable results. Even though Costa Rica's PSA is hardly recognizable as a neoliberal project, certain elements, when influenced by neoliberal policies, have the same effect. 
The reason for this, I suggested in my theoretical discussion, is that neoliberalism is not a monolithic force that displaces previous modes of governance. The "ideal type" characterization of neoliberalism does not represent a metric against which the "neoliberalness" of certain policies can be tested, but is rather a device for conceptualizing a phenomenon (Castree 2008b; McCarthy and Prudham 2004). The "actually existing" neoliberalisms will never map neatly onto this idealized model because varied histories and geographies produce divergent outcomes (Brenner and Theodore 2002; Peck and Tickell 2002). Instead, when understood as an incomplete and adapting process, neoliberalization can be identified in even the most overtly non-neoliberal projects. And as I have attempted to show here, those neoliberalizations can still have important implications. Attention must be devoted to even these incomplete and partial instances of neoliberalization, certainly because they are the only type that ever actually exist.

\section{References:}

Bakker, K., 2009. Neoliberal nature, ecological fixes, and the pitfalls of comparative research. Environment and Planning A, 1781-1787. 
Bennett, K., Henninger, N., 2008. Payments for Ecosystem Services in Costa Rica and Forest Law No. 7575. World Resources Institute, Washington DC.

Blackman, A., Woodward, R., 2010. User financing in a national payments for environmental services program: Costa Rican hydropower. Ecological Economics, 69, 1626-1638.

Brenner, N., Theodore, N., 2002. Cities and the Geographies of “Actually Existing Neoliberalism”. Antipode, 34, 349-379.

Castree, N., 2008a. Neoliberalising nature: processes, effects, and evaluations. Environment and Plan$\operatorname{ning} A$, 40, 153-173.

---, 2008b. Neoliberalising nature: the logics of deregulation and reregulation. Environment and Plan$\operatorname{ning} A$, 40, 131-152.

---, 2009. Researching neoliberal environmental governance: a reply to Karen Bakker. Environment and Planning A, 1788-1794.

Chomitz, K., Brenes, E., Constantino, L., 1999. Financing environmental services: the Costa Rican experience and its implications. The Science of The Total Environment, 240, 157-169.

Daily, G., Söderqvist, T., Aniyar, S., Arrow, K., Dasgupta, P., Ehrlich, P., Folke, C., Jansson, A., Jansson, B., Kautsky, N., Simon, L., Lubchenco, J., Mäler, K., Simpson, D., Starrett, D., Tilman, D., Walker, B., 2000. The Value of Nature and the Nature of Value. Science, 289, 395-396.

Decree 32868-MINAE. Ministry of Environment and Energy, Costa Rica.

Farley, J., Costanza, R., 2010. Payments for ecosystem services: From local to global. Ecological Economics, 69, 2060-2068.

Fletcher, R., Breitling, J., 2012. Market mechanism or subsidy in disguise? Governing payment for environmental services in Costa Rica. Geoforum, 43, 402-411. 
FONAFIFO, 2011. Distribución de montos presupuestario para CAF y PSA.

http://www.fonafifo.go.cr/text_files/servicios_ambientales/Dist_Presu_Montos.pdf. Accessed:

21 September 2011.

Foucault, M., 2008. The birth of biopolitics: lectures at the Collège de France, 1978-79. Palgrave Macmillan, New York.

Harvey, D., 2005a. A Brief History of Neoliberalism. Oxford University Press, New York.

---, 2005b. The New Imperialism. Oxford University Press, New York.

Igoe, J., Brockington, D., 2007. Neoliberal Conservation: A Brief Introduction. Conservation and Society, 5, 432-449.

Katz, C. 1998. Whose Nature, Whose Culture? In: Braun, B., Castree, N. (Eds.) Remaking Reality: Nature at the Millenium. Routledge, New York, NY, pp. 46-63.

Kosoy, N., Corbera, E., 2010. Payments for ecosystem services as commodity fetishism. Ecological Economics, 69, 1228-1236.

Larner, W., Craig, D., 2005. After Neoliberalism? Community Activism and Local Partnerships in Aotearoa New Zealand. Antipode, 37, 402-424.

McAfee, K., 2012. The Contradictory Logic of Global Ecosystem Services Markets. Development and Change, 43, 105-131.

McCarthy, J., Prudham, S., 2004. Neoliberal nature and the nature of neoliberalism. Geoforum, 35, 275-283.

Miranda, M., Porras, I., Moreno, M., 2003. Social Impacts of the Payments for Environmental Services (PES) Scheme in Costa Rica. International Institute for Environment and Development, London. 
Morell, M., 1997. Financing Community Forestry Activities. Unasylva, 188, 36-43.

Ortiz Malavasi, E., 2011. Caracterización del Programa Forestal Huetar Norte (PFHN): Impacto social y fijación de C02. FONAFIFO, San Jose, Costa Rica.

Pagiola, S., 2008. Payments for environmental services in Costa Rica. Ecological Economics, 65, 712724.

Pagiola, S., Arcenas, A., Platais, G., 2005. Can Payments for Environmental Services Help Reduce Poverty? An Exploration of the Issues and the Evidence to Date from Latin America. World Development, 33, 237-253.

Peck, J., 2004. Geography and public policy: constructions of neoliberalism. Progress in Human Geography, 28, 392-405.

---, 2010. Zombie neoliberalism and the ambidextrous state. Theoretical Criminology, 14, 104-110.

Peck, J., Tickell, A., 2002. Neoliberalizing Space. Antipode, 34, 380-404.

Porras, I., 2010. Fair and Green? Social impacts of payments for environmental services in Costa Rica. International Institute for Environment and Development, London.

Rodríguez Zúñiga, J. M., 2003. Paying for Forest Environmental Services: The Costa Rican Experience. Unasylva, 54, 31-33.

Rojas, M., Aylward, B., 2003. What are we learning from experiences with markets for environmental services in Costa Rica? A review and critique of the literature. International Institute for Environment and Development, London.

Sage, L., Sanchez, O., 2002. Evolucion esperada para el mercado de pago de servicios ambientals en Costa Rica. Revista Forestal Centroamericana, 37, 72-73. 
Sánchez-Azofeifa, G. A., Pfaff, A., Robalino, J. A., Boomhower, J. P., 2007. Costa Rica's Payment for Environmental Services Program: Intention, Implementation, and Impact. Conservation Biolo$g y, 21,1165-1173$.

Sierra, R., Russman, E., 2006. On the efficiency of environmental service payments: A forest conservation assessment in the Osa Peninsula, Costa Rica. Ecological Economics, 59, 131-141.

Sills, E., Hartshorn, G., Ferraro, P., Spergel, B., 2005. Evaluation of the World Bank-GEF Ecomarkets Project in Costa Rica. North Carolina State University.

Silva, E., 2003. Selling Sustainable Development and Shortchanging Social Ecology in Costa Rican Forest Policy. Latin American Politics \& Society, 45, 93-127.

Smith, N., 2007. Nature as Accumulation Strategy. Socialist Register, 43, 16-36.

von Platen, H., 1999. Payments for environmental services: a new slogan for old incentives or a new economic concept? Gesellschaft fur Agrarprojekte, 4, 21-30.

Watson, V., Cervantes, S., Castro, C., Mora, L., Solis, M., Porras, I., Cornej, B., 1998. Making Space for Better Forestry. International Institute for Environment and Development, London.

Weber, M., 2007 [1904]. 'Objectivity' in Social Science. In: Calhoun, C., Gerteis, J., Moody, J., Pfaff, S., Virk, I. (Eds.) Classical Sociological Theory, 211-217. Blackwell Publishing, Malden, MA.

Whittington, D., Pagiola, S., 2011. Using Contingent Valuation in the Design of Payments for Environmental Services Mechanisms: A Review and Assessment. World Bank, Washington DC.

World Bank, 2000. Ecomarkets - Project Appraisal Document. The World Bank Group, Washington DC.

---, 2006. Mainstreaming Market-Based Instruments for Environmental Management - Project Appraisal Document. The World Bank Group, Washington DC. 
---, 2007. Ecomarkets - Implementation Completion and Results Report. The World Bank Group, Washington DC.

Wunder, S., Engel, S., Pagiola, S., 2008. Taking stock: A comparative analysis of payments for environmental services programs in developed and developing countries. Ecological Economics, 65, $834-852$.

Wünscher, T., Engel, S. Wunder, S., 2008. Spatial targeting of payments for environmental services: A tool for boosting conservation benefits. Ecological Economics, 65, 822-833.

Zhang, W., Pagiola, S., 2011. Assessing the potential for synergies in the implementation of payments for environmental services programmes: an empirical analysis of Costa Rica. Environmental Conservation, 38, 406-416 